\title{
E Pluribus Unum: The Detection of Political Persuasion Through Discourse Analysis
}

\author{
Lara Mantovan \\ Department of Linguistics and Comparative Cultural Studies \\ Ca’ Foscari University Venice \\ Ca’ Bembo, Fondamenta Tofetti, Dorsoduro 1075, 30123 Venice, Italy \\ Tel: 39-041-234-9480Ｅ-mail: laramantovan@unive.it
}

Received: April 16, 2020

Accepted: June 8, 2020

Published: July 7, 2020

doi:10.5296/ijl.v12i4.16859

URL: https://doi.org/10.5296/ijl.v12i4.16859

\begin{abstract}
Political discourse involves particular lexical choices, grammatical features, rhetorical devices, and nonverbal signals. Politicians often capitalize on them in order to influence recipients' state of mind and persuade them to share their world image. Particular persuasive strategies are used as tools to deliberately manufacture mass consent. On their part, the addressees of political discourse are not often aware of the effects of these particular discourse features in terms of audience control.

This paper aims at discussing discourse analysis as a diagnostic tool for the assessment of power relations and the transmission of ideological beliefs. In the spirit of Critical Discourse Analysis and in particular Fairclough's (1989) ten-question model, the paper proposes a multimodal analysis of Barack Obama's Victory Speech. The study reveals that the detection of political messages (in this case, the importance of national unity) is triggered by the presence of ideologically significant lexical elements, grammatical features, rhetorical techniques, and discourse markers that function as ideological cues. Their simultaneous distribution, together with specific non-verbal markers (i.e. eye gaze and baton signs). contributes to reinforcing the proposed ideological beliefs.
\end{abstract}

Keywords: Social power, Political discourse, Discourse analysis, Barack Obama, National unity 


\section{Introduction}

Language and power is the title of Fairclough's (1989) seminal volume on the crucial role played by language in the production and maintenance of power. However, the relation between these two entities is also something that we can experience in our everyday life. Language allows us to influence the opinion of other people, build up ideologies, create new world images, and even control social and political events. The concept of language as a tool of political and economic power goes back to Protagoras and is highlighted in Van Dijk's (2008: 64) famous quote: "without communication - text and talk - power in society can hardly be exercised and legitimated".

Generally speaking, people hardly notice the power of language in politics and, specifically, in political discourse. This is partially due to the fact that we are overwhelmed by the considerable amount of material that is produced on such issues: official speeches, public debates, joint declarations, interviews, press releases, public addresses, etc. This paper aims at raising awareness about the effects of political discourse on the multitude, suggesting critical discourse analysis as a diagnostic tool for the assessment of audience control and political dominance.

Structurally, the paper consists of three main sections. Section 2 is devoted to the relationship between power and language. Power as such can be exercised in many different ways: persuasion is one of these and is often used in political discourse with the purpose of influencing mental models and achieving broad consensus. In Section 3, special emphasis is placed on discourse analysis, an interdisciplinary approach to the study of language in use. In particular, the reader is introduced to the domain of Critical Discourse Analysis, a tool aimed at detecting ideological assumptions as well as power relations through discourse analysis. The last section of the paper demonstrates how we can apply the theoretical considerations outlined in the previous sections, in particular Fairclough's (1989) ten-question model, to the systematic analysis of Barack Obama's Victory Speech (Note 1). One of the main political messages included in this speech is the importance and need for national unity. The proposed discourse analysis aims at identifying the linguistic elements, rhetorical devices, non-verbal cues, and discourse markers that are designed to convey and emphasize the key concept of national unity. The references and the full transcript in the Appendix help the reader access the various sources cited throughout the paper.

\section{Discourse and the Exercise of Power}

Discourse is generally intended as language in use, i.e. language used in a particular social situation. As such, it is not an autonomous construct, rather it interconnects with the context in which it is produced, and it is shaped by the interaction among participants as well as other external factors (Potter, 2003). Furthermore, discourse is a social product that can actively shape participants' ideas and mental representations. It can influence interpersonal relations and the way people behave, thus contributing to create (an epistemic) reality (Potter \& Wetherell, 2010). This section explores how discourse can be exploited to regulate the exercise of power in modern society. 


\subsection{The Connection Between Language and Society}

According to Fairclough (1989: 20), discourse is a social practice. Society is strongly linked to language and vice versa. On the one hand, social relationships and behaviors can exert influence on the way people talk. This is the research field of sociolinguistics, which is aimed at studying linguistic variation in relation to particular social aspects (for an overview, see Wardhaugh, 2006 and Deckert \& Vikers, 2011). On the other hand, what people say can affect society. The effects of language on society represent the main interest of another discipline, namely the sociology of language (for an overview, see Millar, 2010 and Fishman, 2012).

In order to concretely exemplify the special bidirectional connection between language and society, we can take into consideration a particular work context, such as an office. A new employee would probably try to be as considerate and accommodating as possible towards his employer by using polite and formal expressions. Therefore, the social context would affect his way of speaking and interacting with his boss. Parallelly, the style of speaking adopted by the employee could have a decisive influence in maintaining, and perhaps changing, the social relationships within the office.

\subsection{The Exercise of Power Within Society}

Social relationships among human beings are frequently unequal. We can think of employers and employees, teachers and pupils, team managers and professional sportspeople, etc.: in each social context, we can identify a dominant group and a dominated group. What makes the difference between them is essentially the exercise of power. By this term, we generally mean the ability to exert control over other people. According to the Western society, power is often approached as a form of dominance. Being the subject of scientific research in several disciplines, the literature on power is vast and complex (among others, see Foucault, 1980; Wartenberg, 1990; Hindess, 1996; Wrong, 1997; Lukes, 2005; Zaaiman, 2007; Han, 2019). For this reason, an overview of it is beyond the scope of this article. The specific type of power that is considered here is social power, intended as the control exercised by one group over the actions and/or way of thinking of another group (Van Dijk, 1996: 84).

The control over society typically presupposes the existence of an ideological framework. Ideology, intended as a system of beliefs, is based on practices that spread from a dominant group to the multitude (Nescolarde-Selva, Usó-Doménech \& Gash, 2017). Through a gradual process of naturalization, these practices become universal and commonplace. An ideology is generally considered successful when a lot of people share it. Therefore, ideological assumptions are aimed at producing adherence to a set of ideas and practices and maintaining certain power relations.

The exercise of power within society can assume several forms: force, manipulation, persuasion, and authority (Wrong, 1997). Each form of power activates specific strategies to reach specific goals. For example, force makes use of violence, coercion, or aggressive behaviors in order to establish dominance and power abuse. On the other side of the spectrum, persuasion is a form of power that mainly relies on communication to influence the recipients' 
ideas and mental states. By influencing someone's perspective, it is possible to indirectly change his/her attitude and obtain implicit consent to exercise power. This is a subtler form of control and it allows to a certain extent freedom of action and resistance. Persuasion is designed to circumvent analytical reasoning and access and influence the recipient's world image (Schmidt \& Kess, 1986). For this reason, people are hardly aware of the implications of such a form of power. In the next section, the main features of persuasive discourse are discussed.

\subsection{Persuasive Discourse}

Whereas force and coercion are typically based on violence, persuasion relies more on language (Thomas et al., 2004). To induce the recipients to converge to the desired mental representation, persuaders carefully control discourse features and resort to specific rhetorical means (e.g. metaphors, metonymies, litotes, aphorisms, rhetorical questions, particular rhythmic effects). The main purpose of persuasive discourse is to make people think in a certain way and manufacture their consent and agreement on the proposed beliefs. The social domains where persuasive discourse typically finds application are politics, marketing, prosocial causes, medical decision-making, charity advertising, and so on (O'Keefe, 2016).

Importantly, persuasion does not only affect linguistic choices, but also information selection. Persuaders may benefit from carefully selecting information likely to promote his/her beliefs and a positive self-presentation. This is exemplified by a popular Russian joke, here reported in (1).

(1) "When Nixon visited Moscow, he and Khrushchev had a race around the Kremlin. Nixon came the first. How should our media report on that?" "As follows: In the international running competition the General Secretary of the Communist Party took the honorable second place, while President Nixon came in one before last." (Note 2)

The second part of the joke is an instance of persuasion. Words and details are carefully selected in favor of the interests of the Soviet Union. On the one hand, the Soviet General Secretary, Nikita Sergeyevich Khrushchev, should be praised for his "honorable second place." On the other hand, the joke discredits the US President, Richard Nixon, obfuscating his successful performance. Moreover, an important detail is intentionally omitted: the text does not say anything about the number of participants in the race. The overall effect turns out to be hilarious because reality shows a completely different situation: competitors were not more than two, Nixon came first, and Khrushchev finished last of two.

What this joke highlights is that we can influence the addressee's mind by deliberately omitting some details and giving salience to some others. Persuasive discourse, as well as manipulative discourse, relies on salience: it can be seen as a "deliberate attempt to constrain context selection" (Maillat \& Oswald, 2009: 368). This form of power is designed to expose the addressee to a limited set of contextual assumptions. Such limitation is aimed at influencing his/her mental states and beliefs and validate reality collectively. The implications of persuasion may be: i) the creation of a new salient belief, or ii) the change in the evaluation of an existing belief (O'Keefe, 2016). 
One important aspect of persuasive discourse is speaker interest. To influence the mind of addressees in the speaker's interest, discourse typically enacts "positive self-presentation", and sometimes also "negative other-presentation" (Van Dijk, 2006: 373). In the process of formulating rival positions, speakers may resort to particular linguistic devices, such as personal pronouns and contrastive pairs (Atkinson, 1984; Chilton, 2004; Karapetjana, 2011). The former usually implies boasts about "us" and "our" actions and attacks on "them"; the latter consists of two contrasting parts of similar length which are often joined by a conjunction, such as "and", "or", "but". These two techniques are both exemplified in an extract taken from UK general election in 1979 and reported here in (2).

(2) The Labour Prime Minister and his colleagues are boasting in this election campaign that they have brought inflation down from the disastrous level of twenty-six per cent, but we are entitled to inquire who put it up to twenty-six per cent. (Atkinson, 1984: 76) [Italics added]

\section{Discourse Analysis Applied to Political Discourse}

Discourse analysis is situated at the crossroad of different disciplines, such as linguistics, psychology, history, sociology, and anthropology. However, it has gradually emerged as an independent discipline (for an overview, see Gee, 1999; Charaudeau \& Maingueneau, 2002; Antelmi 2012). In the more linguistic tradition, discourse analysis has been also combined with pragmatics, text linguistics, and the quantitative methods of corpus linguistics (De Beaugrande \& Dressler, 1981; Maingueneau, 2017). Given its multidisciplinary nature, discourse analysis may deal with a wide range of research topics and consider different theoretical perspectives as well as different methodological approaches. For the purpose of the present study, in this section we discuss how the methods of discourse analysis can be applied to political discourse specifically.

\subsection{Detecting Ideological Positions}

Persuasive and manipulative language particularly characterizes discourse used in political contexts. Politicians are aware of the power of their words and capitalize on specific linguistic features to persuade people to see the world in terms favorable to their own interests (Van Dijk, 1996; Chilton, 2004). As Atkinson (1984) observes, brilliant orators are so good at mastering all the technical skills that they can use them in quick succession and in a simultaneous way. In political discourse, the interaction of different semiotic codes and multimodal aspects are often important ingredients used to emphasize political messages in an effective way (Degano, 2016). Several verbal and non-verbal signals can be combined at the same time to encourage the audience to applaud. An effective speech often contains claptraps, i.e. special devices designed to elicit applause, approval, and appreciation (Beard, 2000). For instance, speakers could arouse curiosity and incentive to pay attention by naming someone only after a short introduction (the "guessing game", Atkinson, 1984: 53). Another oratorical technique used to emphasize the importance of a key concept is the three-part list. A few examples are given below.

(3) We hold these truths to be self-evident, that all men are created equal, that they are 
endowed by their Creator with certain unalienable rights, that among these are life, liberty and the pursuit of happiness. (The Declaration of Independence, July 4, 1776) [Italics added] (Note 3)

(4) Government of the people, by the people, for the people. (Lincoln A., Gettysburg Address, November 19, 1863) [Italics added] (Note 4)

(5) True peace is not merely the absence of some negative force-tension, confusion or war; it is the presence of some positive force-justice, good will and brotherhood. (King Jr. M. L., Nonviolence and Racial Justice, The Christian Century 74, February 6, 1957) [Italics added] (Note 5)

The choices orators make through political discourse may be motivated by the communicative intent (e.g. discrediting opposition leaders, improving their own image, mobilizing mass opinion, and gaining the support of people), the socio-historical context, and the characteristics of the audience (Santulli, 2004, 2010). Therefore, linguistic choices concerning vocabulary, grammar, and textual structures are often ideologically motivated (Section 2.2). To detect information related to social and political dominance, discourse analysis proves as a useful tool.

\subsection{Political Discourse Analysis}

Discourse analysis applied to political texts may assume different theoretical perspectives and account for several linguistic aspects (for an overview, see Van Dijk, 1997; Chilton, 2004; Okulska \& Cap, 2010; Kampf, 2015).

One of the main approaches to the analysis of political discourse is represented by the Critical Discourse Analysis (CDA) framework (Fairclough \& Wodak, 1997; Pêcheux, 1982; Wodak \& Meyer, 2001; Wodak \& Chilton, 2005; Wodak, 2007; Fairclough, 2010). For the purpose of the discussion, it is only briefly outlined here. CDA proposes a multidisciplinary approach to discourse analysis to detect social and power relations as well as ideological usages of language. In this view, the analysis of political text has the potential to unmask social inequalities and power abuse. This approach, initiated in the late 1970s, does not limit to the analysis of text structures, but crucially considers them in interaction with the context taken from several perspectives (e.g. social, political, historical, cultural, and psychological).

Fairclough (1989: 110-112) conceptualizes CDA in a list of ten questions and a number of sub-questions aimed at guiding the analysis of a text considering several aspects. On the basis of Fairclough's list, let us exemplify some relevant linguistic features concerning vocabulary, grammar, and textual structures. For illustrative purposes, the discussed features are contextualized in real political scenarios.

\subsubsection{Vocabulary}

In the category of vocabulary, Fairclough (1989) mentions lexical choices, ideologically significant terms, euphemisms, and metaphors.

The choice of wording may reflect the beliefs that the orator aims at delivering. In particular, 
the terminology chosen in a speech can be used as ideological cues, in that it is directly or indirectly associated with certain ideological assumptions. For example, Jihadist Kamikaze-bombers may be defined by using different nouns, including "martyrs", "warriors", "terrorists", "murderers", etc. Crucially, the lexical choice made by the speaker distinctly reflects his/her ideological beliefs. Moreover, the speaker's evaluation of an event may be detected by the choice to use particular adjectives, adverbs, or other parts of speech potentially endowed with ideological value.

Euphemisms enable the speaker or writer to avoid being too direct or maybe even offensive to certain groups of people. Taboo subjects that often need the use of euphemisms are death, war, and sex. Abraham Lincoln, in his Gettysburg Address (Note 6) in 1863, refers to death as "a final resting place" and "the last full measure of devotion." Another example of euphemism in political discourse is the well-known expression "final solution of the Jewish question", used by Nazi officials to refer to the mass extermination of Jews. It was documented in the Wannsee Protocol (Note 7) (January 20, 1942), the minutes of the Wannsee Conference.

Metaphors are rhetorical devices used to establish a connection between two different areas of knowledge without resorting to connectors such as like or as. Politicians may use metaphors to provide vivid images and explain a situation in a dazzling way (Section 4.4.3). During interviews and press-releases, politics may be associated with other domains, such as war or sport. During an interview in 2004, the US President George W. Bush stated the sentence reported in (6) referring to Senator Kerry and his judgments of hindsight.

(6) But a Monday morning quarterback has never led any team to victory. (G. W. Bush, Remarks in Cuba City, Wisconsin, October 26, 2004) (Note 8)

"A Monday morning quarterback", "team", and "victory" are linguistic expressions belonging to the field of sports. This comparison is aimed at striking the audience and poking fun at Bush's opponent. The audience, indeed, responded with applause.

\subsubsection{Grammar}

Switching from vocabulary to grammar, we should consider the effect of particular syntactic structures and grammatical aspects. In his ten-question model, Fairclough (1989) asks whether nominalizations are used and whether sentences are active or passive. These structures appear to have something in common. Both agentless passive sentences and nominalization do not provide information about the agent. A speaker could employ these two devices to obfuscate relations of causality and avoid dealing with responsibility in a direct way. For instance, we could imagine a group of doctors who do not want to say that a few of them have underestimated the negative consequences of a surgical intervention. On the occasion of a press release, it could be convenient for the spin doctor to utter the passive sentence in (7) a, instead of saying the active sentence in (7) b.

(7) a. Mistakes were made in evaluating the situation.

b. Some of us made mistakes in evaluating the situation. 
The sentence in (7) a allows the speaker to evade responsibilities and soften the impact of the statement.

Even the choice between different forms of personal pronouns can give us information about power relations. The next example demonstrates that the first plural person includes political commitment, whereas the second plural person excludes a personal involvement (Section 4.4.2). On May 19, 1940, Sir Winston Churchill delivered his first broadcast as Prime Minister to the British people. At the beginning of the speech, by saying the sentence reported in (8), he aimed at arousing concern about the German attack.

(8) We must not allow ourselves to be intimidated by the presence of these armoured vehicles in unexpected places behind our lines. (Churchill W., Be Ye Men of Valour, May 19, 1940) (Note 9)

The use of the first plural person makes the issue seem more relevant to the listeners. Everyone, the Prime Minister included, should deal with the fear of being attacked. This linguistic choice narrows the gap between politicians and citizens and directly engage the audience. If Churchill had opted for the second plural person, as shown in (9), the result would have been a sense of detachment and lack of personal involvement in the situation.

(9) You must not allow yourself to be intimidated by the presence of these armoured vehicles in unexpected places behind our lines.

Ideological beliefs may also be detected by analyzing the use of connectors and cohesion. The way in which phrases and clauses are linked together may open a window on logical relations and the speaker's line of reasoning. For example, adversative connectors as "but" and "however" are frequently used to reinforce a negative presentation of the other or introduce a contrast between two arguments.

\subsubsection{Textual Structures}

Another source of information concerning power relations is textual structure, conceived as the way the whole text is formally organized and structured (Fairclough, 1989).

The expression textual structures includes the main features of the text (e.g. discourse type, text layout, organization of the topics, episode marking), the relation between text and context, interaction, and turn-taking. As for written texts, large-scale structures reveal in what order political positions are introduced and combined. As for oral texts in the form of interviews or debates, the turn-taking system and the interactional conventions are important aspects worth considering. If a politician frequently interrupts the speaking flow or rewords what has been previously said, this means that he or she wants to control the contributions of the addressee, who generally turns out to be less powerful. To illustrate how textual structures may reveal unequal social relations, we consider a text taken from Fairclough (1989: 18) and reported here in (10). It is a discourse stretch referring to an interview at a police station. Even if it is not a direct example of political discourse, it is relevant to textual structures. This extract involves a policeman (P) and the witness to an armed robbery (W).

P: What sort of age was he? 
W: About 45. He was wearing a...

P: And how tall?

W: Six foot one. (...)

P: (...) What about his clothes?

W: He was a bit scruffy-looking, blue trousers, black...

P: Jeans?

W: Yeah.

The witness is limited to answering the questions, whereas the policeman intervenes whenever he wants and does not care much about the emotional state of the addressee. He has direct control over communication, with the result that he appears in a more powerful position.

\section{Barack Obama's Victory Speech}

Building on the theoretical aspects previously discussed, this section aims at further investigating the connection between linguistic devices and ideological assumptions by presenting a qualitative analysis of a well-known political speech, Barack Obama's Victory Speech (November 4, 2008). On this special occasion, Obama spoke publicly in front of a vast crowd in his home city of Chicago, Illinois. According to a government estimate, the number of people gathered at Grant Park was at least 240000.

One of the main political ideas conveyed by his words is the need for national unity. In the spirit of Fairclough's (1989) approach to CDA (Section 3.2), the analysis proposed here aims at identifying the elements that turn out to be ideological significant and concur in sending a political message to the audience. Interestingly, all these elements are not mutually exclusive, rather are combined simultaneously: this layering distribution contributes to making the speaker's message more effective and noticeable.

The full transcript of the speech is available for readers at the end of the paper, in the Appendix. Direct quotations are always followed by the corresponding line numbers (introduced by "l." or "ll.") which enables clear cross-references.

\subsection{The Content of the Victory Speech}

Contentwise, the Victory Speech can be divided into five main sections. The switch from one topic to another appears clear-cut.

I. The opening section (11. 1-15) is aimed at celebrating the victory at the presidential elections. The recurring theme in this part is change ("change has come to America", 1. 15).

II. In the second section (11. 16-43), Obama expresses his gratitude to several people. First of all, his thoughts turn to his opponents (Senator McCain and Governor Palin), then to the closest allies (the Vice President-elect Joe Biden), his campaign manager (David Plouffe), 
and his chief strategist (David Axelrod). Afterward, he thanks his wife, daughters, grandmother, and siblings for their support. Last but not least, he thanks all his voters.

III. The third section (11. 44-88) begins with the major problems of the past and continues with the greatest challenges of the future. Obama commits himself to face each problem and encourages Americans to take responsibility for changing the country. He also affirms the concept of national unity despite political divides.

IV. The fourth section (11. 89-110) includes the story of a 106-year-old woman who has witnessed many changes in her long life. With this anecdote, Obama wants to reach the many through the story of one person.

$\mathrm{V}$. The conclusion of the speech (11. 111-120) presents expectations for the future and the final call to action.

\subsection{E Pluribus Unum: The Political Message}

Despite the variety of contents, the Victory Speech presents a recurring theme: the sense of national unity. From the beginning to the end, Obama intends to inspire a cooperative spirit within the American community and a strong feeling of belonging to the nation.

He mentions the common historical background (i.e. sex and racial discrimination, the moon landing, the fall of communism), widespread problems (e.g. paying mortgages, medical expenses, college fees, and also "a planet in peril, the worst financial crisis in a century", 11 . 46-47) and shared values ("democracy, liberty, opportunity and unyielding hope", 11. 85-86), hence the idea of the collective. For the nation's sake, Obama wishes a cooperative relationship with his opponents. The speech itself is intended to reach both voters and supporters of the Opposition ("I will be your President too", 1. 78). The main purpose of the speaker is to invite all Americans to take responsibility for changing the country. In this inclusive vision, Democrats and Republicans should avoid partisan conflicts and fight together to reach common goals.

In the final lines, we can find an assertion that summarizes the unifying intent of the whole speech: "Out of many, we are one" (11. 117-118). It directly calls to mind the inscription of the Great Seal of the United States of America, namely "E pluribus unum" (Figure 1).

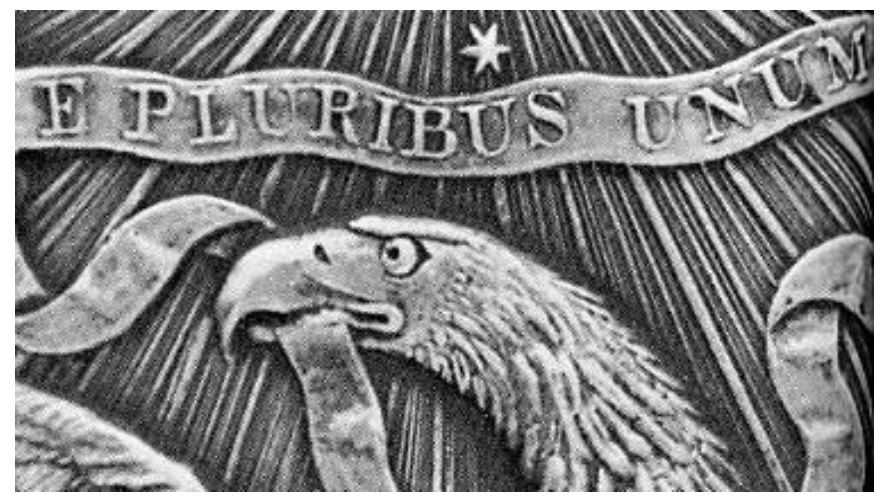

Figure 1. The inscription "E pluribus unum" on the scroll carried in the beak of the American bald eagle (Great Seal of the United States of America). (Note 10) 


\subsection{Discourse Analysis of the Victory Speech}

Throughout the text, the concept of national unity is highlighted by the use of several elements combined together. The following sections present an in-depth qualitative analysis of these elements, taking into account the aspects discussed in the literature review (Sections 2 and 3). In particular, the analysis is based on traditional discourse categories, such as vocabulary (Section 4.3.1) and grammar (Section 4.3.2), but it also looks at two additional categories: the use of non-manual cues (Section 4.3.3) and intertextuality (Section 4.3.4). Since communication is multimodal, discourse analysis should not be limited to the linguistic features included in the text, but it should also consider the contribution of the hand gestures and visual cues simultaneously produced with the speech. The important role of these paralinguistic elements in political discourse has been already discussed by a number of studies (Bull, 1986; Bucy \& Bradley 2004; Poggi \& Vincze, 2009). Furthermore, since political discourse often refers back to previous speeches (Kitaeva \& Ozerova, 2019), textual interconnections are also considered.

\subsubsection{Vocabulary and Lexical Choices}

It is worth providing a comprehensive overview of the lexical choices involved in the speech. First of all, we should remark that a high-frequency lexicon is used. For example, instead of talking about the lack of remunerative employment, Obama mentions "jobs that offered little pay" (11. 39-40). He deliberately avoids technical terms and makes himself clearly understood because he wants to gather up people from all social classes. According to his main message, change is something that everybody can hope for and fight for. The 44th US President claims that change is not only a possibility but also a duty. It is conceived as a collective responsibility. Since nobody should be left out of this special project, the speaker adopts a highly inclusive vocabulary.

If we look at the text carefully, we can identify numerous lexical expressions that are linked to the idea of national unity. Some examples with related observations are listed in Table 1.

Table 1. Lexical expressions referring to the idea of national unity

\begin{tabular}{lll}
\hline Quotation & $\begin{array}{l}\text { Line } \\
\text { number }\end{array}$ & Connection to the idea of national unity \\
\hline "we as a people" & 1.55 & $\begin{array}{l}\text { These are inclusive forms highlighting that } \\
\text { anyone can be considered the addressee of } \\
\text { Obama's discourse. }\end{array}$ \\
\hline "our people" & 1.115 & $\begin{array}{l}\text { This expression is aimed at including } \\
\text { everyone in the change inspiring a sense of } \\
\text { "I will ask you join in the } 1.59\end{array}$ \\
$\begin{array}{l}\text { work of remaking this } \\
\text { nation" }\end{array}$ & $\begin{array}{l}\text { Putting emphasis on numeral "one", Obama } \\
\text { appeals for national unity in order to reach } \\
\text { common goals. }\end{array}$ \\
$\begin{array}{l}\text { as one people" } \\
\text { "those are values we all }\end{array}$ & 1.73 & $\begin{array}{l}\text { Despite political divides, Democrats and } \\
\text { Republicans "share" the same basic values. }\end{array}$ \\
\hline share"
\end{tabular}




\begin{tabular}{lll}
\hline "I will be your President too" & 1.78 & $\begin{array}{l}\text { The rejection of partisanship reinforces the } \\
\text { idea of national unity. }\end{array}$ \\
\hline "our ideals" & 1.85 & $\begin{array}{l}\text { Americans are all connected by the same } \\
\text { traditional beliefs. }\end{array}$ \\
\hline "our union can be perfected" & 1.87 & $\begin{array}{l}\text { This is a direct reference to the American } \\
\text { people seen as a "union", a single entity. }\end{array}$ \\
\hline
\end{tabular}

Obama's well-known slogan, "yes we can" is a leitmotif of his political campaign. In the last part of the speech, he repeats it seven times (11. 98, 100, 102, 104, 106, 110, 120). This repetitive sequence triggers the collective response of the listeners. People are invited to join in as a chorus repeating the catchphrase. It may sound like a refrain. The speaker encourages the audience to participate as gospel singers involve religious people during the Holy Mass. In this context, repetition reinforces the idea of togetherness. This particular technique appears also in the thank-you section: "this victory truly belongs to you. It belongs to you" (1. 33). Once more the President tries to create a special link between him and the people: in this way, the speech is not just about him, but about them.

Obama often addresses his people using words such as "America" (used 13 times) and "Americans" (used 4 times). These are so-called purr words. They are characterized by a particularly positive connotation and convey a positive and optimistic attitude to the listeners. Besides, the terms "America" and "Americans" reinforce the sense of patriotism and belonging to the motherland. In two short extracts from the speech ("but America, I have never been more hopeful than I am tonight that we will get there", 1. 54; "America, we have come so far", 1. 111), the 44th US President addresses the nation with particular familiarity, generating a strong vocative effect.

Moreover, Obama addresses specific groups of people and he carefully avoids offensive and politically incorrect language (Section 3.2). For example, he says "not-so-young people" (1. 40) instead of "old people" or "elderly". He also refuses to use sexist elements not to exclude women. In the text, we can find some examples of gender-inclusive language: "men and women" (1. 22), "working men and women" (1. 37), "mothers and fathers" (1. 49). Also, neutral expressions like "many" (1. 5), "Americans" (1. 8), "those" (1. 11), "people" (1. 97) are used in order to avoid gender-specific lexicon.

In the middle of the speech, Obama repeatedly resort to the rhetorical device of metaphor (Section 3.2). He establishes a comparison between two different groups of people: on the one hand Americans, on the other hand soldiers involved in a war. The expressions "this victory" (11. 62-63), "a new spirit of service" (11. 64-65), "a new spirit of sacrifice" (1. 65), "a new spirit of patriotism" (1. 66) clearly allude to military conflicts. The hidden message behind these words is that Americans should work hard and cooperate with each other like soldiers within the same regiment. The idea is that, in return for personal effort, they will earn glory and honor.

Another rhetorical device used in the speech is analogy, with which Obama aims at narrowing the gap between him and the listeners, comparing himself to any other man. The sentence "Sasha and Malia, I love you both so much, and you have earned the new puppy 
that's coming with us to the White House" (11. 26-27) indicates that Obama wants to show himself as an ordinary family man. He expresses affectionate thoughts about his daughters, then he thanks his wife for her love and support, and he is also grateful to his relatives, especially to his grandmother. This whole paragraph is aimed to depict him as a normal person so that anyone can relate to what he is saying.

The last part of the speech presents another effective analogy: the whole American people are compared to Ann Nixon Cooper, an African-American centenarian from Atlanta ("she's a lot like the millions of others who stood in line to make their voice heard in this election," 11. 90-91). She witnessed numerous historical, political, and social changes throughout her life but her attitude towards life has always been optimistic ("she knows how America can change," 11. 109-110). Obama includes details to make this story as vivid as possible. Thanks to this concrete example concerning one single person, he wants to send a message to everybody. The American people have faced several challenges thus far and they should keep on working together to improve their lives and increase the national prosperity accordingly.

\subsubsection{Grammatical Features}

The relationship between speaker and audience is reflected not only in lexical choices but also in grammatical structures. Apart from the opening if-clause with three who-clause embeddings and a few other cases, Obama generally employs syntactically simple constructions ("America, we have come so far. We have seen so much. But there is so much to do", 1. 111). Generally, tortuous syntactic structures fail in reaching the multitude.

According to Fairclough's (1989) observations (Section 3.3), the use of personal pronouns can shed light on the general approach of the orator. At the beginning, Obama underlines the historical importance of the event and takes a detached view by referring to the Americans by "you" ("tonight is your answer", 1. 3) or "they" ("they believed that this time must be different", 1. 6). Throughout the speech, he often uses the first singular person to show a clear sense of involvement in the national affairs and the willingness to make a personal commitment ("I promise you", 11. 54-55; "I will listen to you", 1. 58). Nonetheless, the personal pronoun most prevalently used is the first plural person. It seldom refers to the President and his political party in an exclusive way ("we didn't start with much money," 1. 34; "our campaign", 1. 35). "We" is frequently used as addressee-inclusive form since it includes the speaker and the whole American people ("we rise or fall as one nation", 1. 69), establishing a close link between the two sides. This pronominal preference is sustained by quantitative data. According to Ye (2010), pronominal forms in this speech are distributed as follows: $56 \%$ are first-person plural pronouns, $19 \%$ are first-person singular pronouns, $13 \%$ are second-person singular pronouns. Third-person singular and plural pronouns are only marginally used. The purpose of this pronominal choice is to allow people to identify with the speaker and foster a sense of shared responsibility ("our climb will be steep", 1. 53). Such an inclusive process culminates in the powerful sentence "we are, and always will be, the United States of America" (11. 9-10) and in the catchphrase "yes we can" (1. 120).

Some phrases and word combinations are worth mentioning. Obama often conjoins words, creating contrastive pairs (i.e. conjunctions of words carrying opposite meanings). The first 
section of the speech provides a list with plenty of pairs ("young and old", "rich and poor", "Democrat and Republican", "gay, straight", "disabled and not disabled", 11. 7-8). These constructions are aimed at involving the entire nation without ignoring internal diversity due to different age, social class, political convictions, sexual orientation, physical and psychical abilities. A contrastive pair is not necessarily made up of two single words. It can contrast also two phrases or sentences, as in the following example: "each of us [...] look after not only ourselves, but each other" (11. 66-67). This is a pair that rejects the idea of individualism and puts special emphasis on the concept of unity and mutual cooperation.

Another particular combination of words and phrases is the so-called three-part list (Section 3.1). This technique sounds attractive to listeners because it provides a satisfying rhythm and adds a sense of completeness to the utterances. In the trio of values mentioned at 11. 72-73 ("a party founded on the values of self-reliance, individual liberty and national unity"), Obama places the idea of unity at the end of the list underlining its importance. The last position of the list is commonly considered as the most prominent. At the beginning of the speech (ll. 8-10), semantic contrast and three-part list are combined together. The President introduces three items, namely the Red States, the Blue States, and the United States of America. His purpose is to eliminate the ongoing debate between Democrats and Republicans and unify different political orientations to achieve common objectives.

\subsubsection{Non-Verbal Cues}

Ideological beliefs may be conveyed not only by speech, but also by nonverbal signals. Listeners are seldom aware of the real meaning of posture, gestures, head movements, facial expressions, and eye gaze direction. This happens because more attention is usually paid to the auditory signal than to body language. In the case of Obama's Victory Speech, both codes contribute to the message transmission. For this reason, the plain transcript of the speech would not be enough for an in-depth analysis: it must be supported by the video recording, which can add further details to the investigation. (Note 11)

In public events, it occurs quite frequently that speakers look directly into the camera to receive cues from the teleprompter. Conversely, Obama intentionally looks at both sides of the audience throughout his speech. He never stares at one specific point. His eye gaze repeatedly turns right (Figure 2) and left (Figure 3) so that nobody in the audience feels excluded.

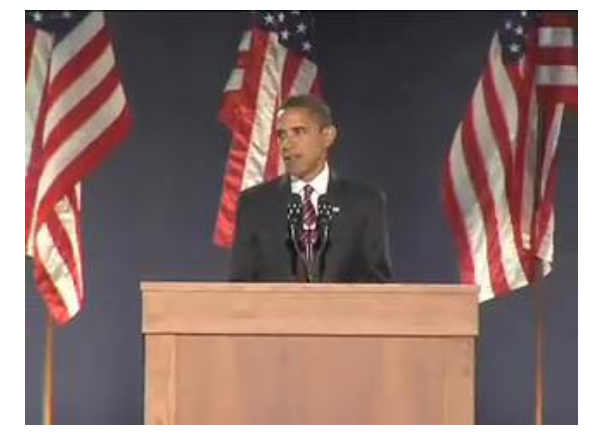

Figure 2. Gaze to the right $(01: 12)$ 


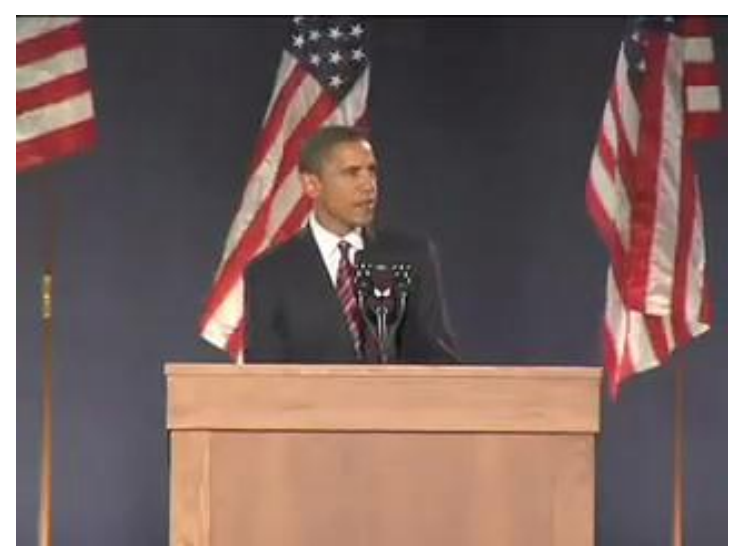

Figure 3. Gaze to the left (01:17)

Gestures, i.e. the movements performed by hands and arms, are often associated with discourse and its meanings. Specifically, baton signs help beat the tempo of the speech creating special emphasis on certain words. Obama uses them several times to hammer home specific messages and reinforce the concept of national unity. Below, some baton signs are discussed and shown. They are presented not in isolation, but in correspondence with the uttered words to highlight the association between verbal and non-verbal communication.

When Obama says "a government of the people, by the people and for the people" (11. 42-43), he uses a thumb-to-forefinger hand configuration (Figure 4). This particular gesture conveys a sense of precision and stresses a particularly marked rhythm.

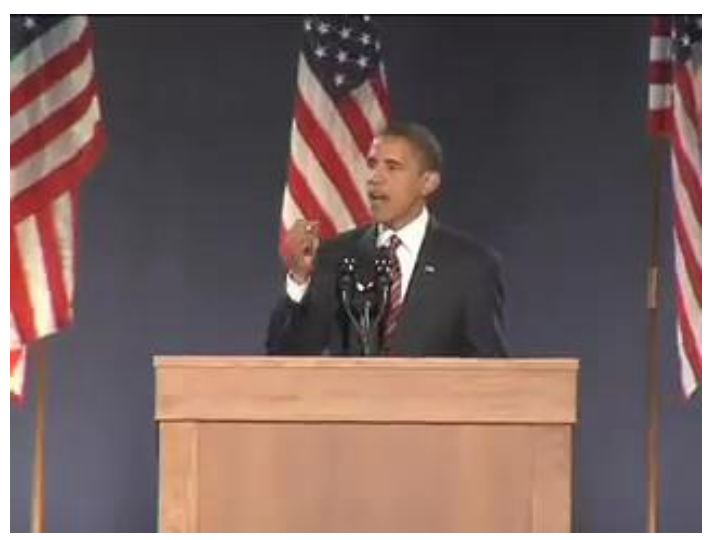

Figure 4. Thumb-to-forefinger (07:20)

The expression "we as a people" (1. 55) is accompanied by a raised forefinger (Figure 5). This baton sign is used to beat the point across and emphasize once again the concept of community. 


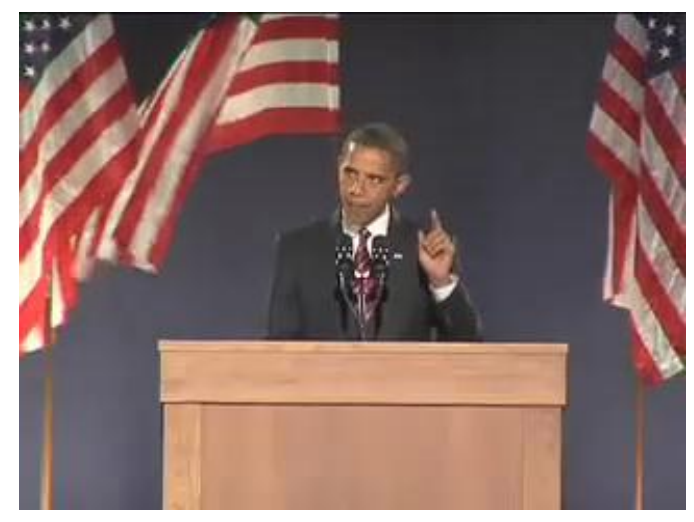

Figure 5. Raised forefinger (08:52)

A few seconds later, Obama shows both his fists, as illustrated in Figure 6. This is a power-oriented gesture, which adds particular strength to the words "a new spirit of service" (11. 64-65).

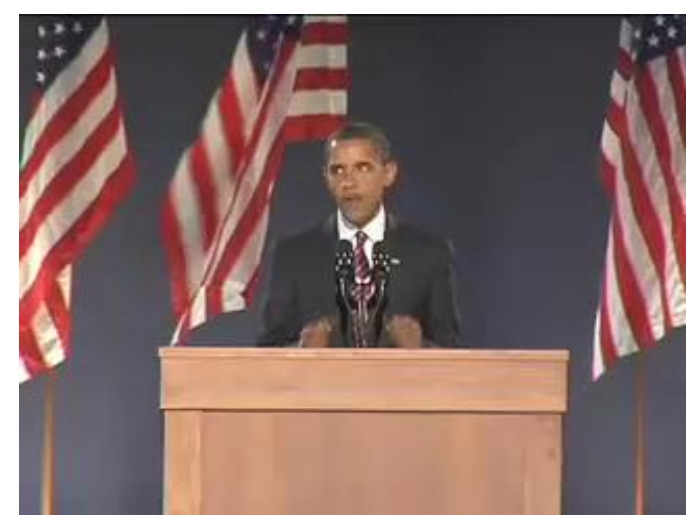

Figure 6. Fists (10:05)

Then, when he talks about a hopefully cooperative relationship between Democrats and Republicans (11. 70-71), Obama shows parallel hands. This gesture, shown in Figure 7, demonstrates a collaborative attitude and a bridge towards the audience.

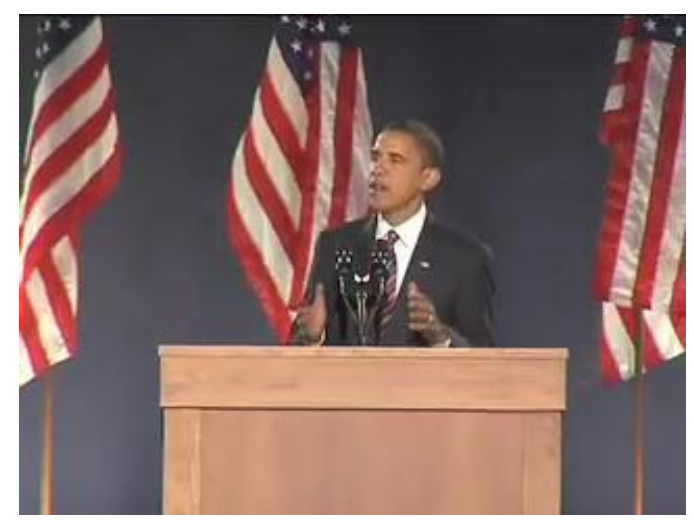

Figure 7. Parallel hands (10:41) 


\section{Ml Macrothink}

International Journal of Linguistics

ISSN 1948-5425

2020, Vol. 12, No. 4

Obama is addressing not only his own people but also other nations. The palms of his hands towards the audience (Figure 8) indicate that he is willing to metaphorically embrace the rest of humanity ("our stories are singular but our destiny is shared", 11. 80-81).

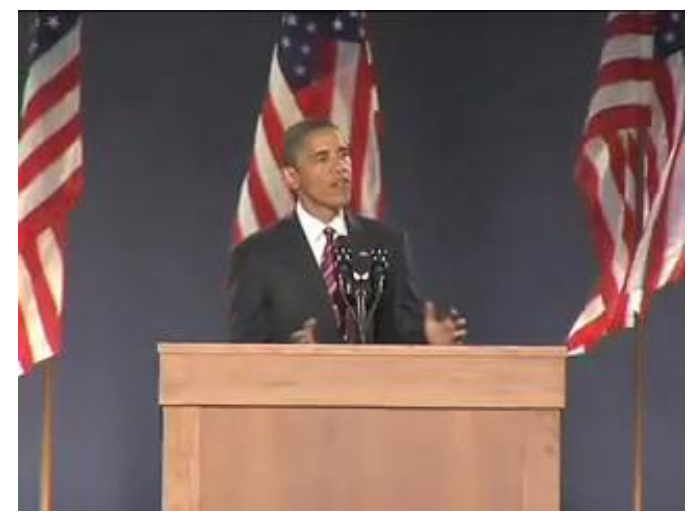

Figure 8. Palms towards the audience (12:06)

\subsubsection{Intertextuality}

To conclude, the text itself is not the only source to conduct an exhaustive investigation. Intertextuality and references to other texts should also be taken into account because the idea of national unity is reinforced by some authoritative and well-known quotations.

First of all, Obama echoes Abraham Lincoln's famous sentence: "a government of the people, by the people and for the people" (11. 42-43). This is the conclusion of The Gettysburg Address, which was delivered at the dedication of the Soldiers' National Cemetery in Gettysburg, Pennsylvania on November 19, 1863. Lincoln considered the American Civil War (1861-1865) as "a new birth of freedom", an event that would create a unified nation. With the aforementioned phrase, he wanted to affirm the principles of democracy, political rights, and equality.

Another quotation which produces an inclusive effect is "I promise you, we as a people will get there" (11. 54-55). It is evocative of Martin Luther King's speech entitled I've Been to the Mountaintop. The Afro-American activist delivered it in Memphis, Tennessee on April 3, 1968 , on the eve of his assassination. He assured his people of the final victory with the following words: "We as a people will get to the promised land". This promise had a religious connotation and was addressed to striking sanitation workers in Memphis and more generally to the Black population, whereas Obama's purpose is to reach the entire American community.

After a few paragraphs, Obama directly mentions the 16th President of the United States: "As Lincoln said to a nation far more divided than ours, we are not enemies, but friends...though passion may have strained it must not break our bonds of affection"' (11. 75-77). This quotation brings to mind Lincoln's first inaugural address on March 4, 1861, on the Eve of the American Civil War. At the close of this speech, he called for national unity inviting his fellow-citizens to overcome the North-South divide. This quotation expresses Obama's hope for reconciliation between Democrats and Republicans in support of national unity. 


\section{Macrothink}

The last quotation concerning the call for national unity is "out of many, we are one" (11. 117-118). As anticipated in Section 4.2, it alludes to the Latin phrase "E pluribus unum" (Eng. "out of many, comes one"). (Note 12) It first appeared on the Great Seal of the United States in 1776 (Figure 1). The bald eagle clutches in its beak a scroll inscribed with the motto " $\mathrm{E}$ pluribus unum". It symbolizes unity in diversity and, thus, it can be applied to the American melting pot. Out of many ethnic groups, religions, social classes, and cultural traditions, Americans emerge as a single people.

\section{Conclusion}

Language cannot change reality, but it can have an influence on the way people perceive reality. According to the Russian joke reported in Section 2.3, at the end of the race Nixon came first whereas Khrushchev finished last of two. No-one can deny it, that is a fact. Nonetheless discourse, especially persuasive discourse, may induce people to think the exact opposite.

Overall, the qualitative analysis of Obama's Victory Speech shows that the link between discourse and social power can be captured by paying attention to: i) particular linguistic features included in the text (lexical and stylistic choices, syntactic structures, rhetorical devices), ii) co-speech nonverbal signals, and iii) intertextual connections and their ideological implications. These aspects combined together create coherent bundles of information and strengthen the main political message of the speech, i.e. the importance of national unity.

The implications of language in politics are not easy to recognize and evaluate. Discourse analysis in this particular field is of particular interest to linguists and not only: it can be useful also to both sides of the power struggle. From the viewpoint of politicians, some of them may be interested in developing new strategies to achieve broad consensus and persuade people to see the world in terms favorable to their own interests and ascendancy. This is why the speechwriter, who is assigned to prepare effective and influential speeches, is a key figure in modern politics. From the viewpoint of citizens, discourse analysis can play a role in raising awareness about what politicians say or write. In fact, the influence on their mental models is not overt and the control over future actions is indirect and subtle. Political messages are not to be taken at face value; people can benefit from explicit analyses so that they become proficient in detecting the difference between what is ideological and what is purely factual.

\section{References}

Antelmi, D. (2012). Comunicazione e analisi del discorso. Torino: UTET.

Atkinson, M. (1984). Our Masters' Voices. The Language and Body Language of Politics. London: Metheuen.

Beard, A. (2000). The Language of Politics. London: Routledge. 


\section{Macrothink}

International Journal of Linguistics

ISSN 1948-5425

2020, Vol. 12, No. 4

Bucy, E. P., \& Bradley, S. D. (2004). Presidential Expressions and Viewer Emotion: Counter Empathic Responses to Televised Leader Displays. Social Science Information, 43(1), 59-94. https://doi.org/10.1177/05390184040689

Bull, P. E. (1986). The Use of Hand Gestures in Political Speeches: Some Case Studies. Journal of Language and Social Psychology, 5, 102-118. https://doi.org/10.1177/0261927X8652002

Charaudeau, P., \& Maingueneau, D. (2002). Dictionnaire d'analyse du discours. Paris: Seuil.

Chilton, P. (2004). Analysing Political Discourse Theory and Practice. London: Routledge. https://doi.org/10.4324/9780203561218

De Beaugrande, R., \& Wolgang, D. (1981). Introduction to Text Linguistics. London: Longman. https://doi.org/10.4324/9781315835839

Deckert, S. K., \& Caroline, H. V. (2011). An Introduction to Sociolinguistics: Society and Identity. London: Bloomsbury.

Degano, C. (2016). Electoral Posters' Second Life: Intertextuality in the 2010 UK Electoral Campaign. In M. Degani, P. Frassi, \& M. I. Lorenzetti (Eds.), The Languages of Politics/La politique et ses langages (Vol. 2, pp. 67-90). Newcastle upon Tyne: Cambridge Scholars Publishing.

Fairclough, N. (1989). Language and Power. Essex: Longman.

Fairclough, N. (2010). Critical Discourse Analysis, the Critical Study of Language. Harlow: Longman.

Fairclough, N., \& Wodak, R. (1997). Critical discourse analysis. In D. T. Van (Ed.), Discourse as Social Interaction (pp. 258-284). London: Sage.

Fishman, J. A. (2012). Readings in the Sociology of Language. Berlin \& Boston: De Gruyter Mouton.

Foucault, M. (1980). Power/Knowledge. Brighton, UK: Harvester.

Gee, J. P. (1999). An introduction to Discourse Analysis. Theory and Method. London: Routledge.

Han, B.-C. (2019). What is power?. Cambridge: Polity Press.

Hindess, B. (1996). Discourses of power: from Hobbes to Foucault. Oxford: Blackwell Publishers Ltd.

Kampf, Z. (2015). Political Discourse Analysis. In K. Tracy, T. Sandel, \& C. Ilie (Eds.), International Encyclopedia of Language and Social Interaction (pp. 1160-1175). Oxford: Wiley-Blackwell.

Karapetjana, I. (2011). Pronominal Choice in Political Interviews. Baltic Journal of English Language, Literature and Culture, 1, 36-45. 
Kitaeva, E., \& Ozerova, O. (2019). Intertextuality in Political Discourse. In Ö. Çakirtaş (Ed.), Language, Power, and Ideology in Political Writing: Emerging Research and Opportunities (pp. 143-170). Hershey, Pennsylvania, USA: IGI Global. https://doi.org/10.4018/978-1-5225-9444-4.ch007

Lukes, S. (2005). Power: A radical view. Basingstoke: Palgrave Macmillan.

Maillat, D., \& Oswald, S. (2009). Defining Manipulative Discourse: The Pragmatics of Cognitive Illusions. International Review of Pragmatics, 1, 348-370. https://doi.org/10.1163/187730909X12535267111651

Maingueneau, D. (2017). Discours et analyse du discours: Une introduction. Paris: Armand Colin.

Millar, R. M. (2010). Sociology of Language: An Introduction. In R. Millar (Ed.), Authority and Identity. A Sociolinguistic History of Europe before the Modern Age (pp. 10-18). Basingstoke: Palgrave Macmillan. https://doi.org/10.1057/9780230282032_2

Nescolarde-Selva, J. A., Usó-Doménech, J.-L., \& Gash, H. (2017). What Are Ideological Systems?. Systems, 5(1), 21. https://doi.org/10.3390/systems5010021

O'Keefe, D. J. (2016). Persuasion: Theory and research (3rd ed.). Los Angeles, CA: Sage.

Okulska, U., \& Cap, P. (2010). Perspectives in Politics and Discourse. Amsterdam: John Bejamins.

Pêcheux, M. (1982). Language, Semantics and Ideology. London: Macmillan.

Poggi, I., \& Vincze, L. (2009). Gesture, gaze and persuasive strategies in political discourse. In M. Kipp, J. C. Martin, P. Paggio, \& D. Heylen (Eds.), Multimodal corpora, Lncs (vol. 5509, pp. 73-92). Heidelberg: Springer. https://doi.org/10.1007/978-3-642-04793-0_5

Potter, J. (2003). Discourse analysis and discursive psychology. In P. M. Camic, J. E. Rhodes, \& L. Yardley (Eds.), Qualitative research in psychology: Expanding perspectives in methodology and design (pp. 73-94). Washington DC: American Psychological Association.

Potter, J., \& Wetherell, M. (2010). Discourse and social psychology. London: Sage.

Santulli, F. (2004). La prima persona plurale: interpretazioni semantiche e pragmatiche. In A. Cardinaletti, \& F. Frasnedi (Eds.), Intorno all'italiano contemporaneo. Tra linguistica e didattica (pp. 245-265). Milano: FrancoAngeli.

Santulli, F. (2010). Costruire il mito tra l'enunciazione e la performatività: Obama et alii. In D. Montini (Ed.), Visione politica e strategie linguistiche (pp. 65-76). Soveria Mannelli: Rubbettino.

Schmidt, R., \& Kess, J. K. (1986). Television Advertising and Televangelism: Discourse Analysis of Persuasive Language. Philadelphia: John Benjamins Publishing Company.

Thomas, L., Wareing, S., Singh, I., Peccei, J. S., Thornborrow, J., \& Jones, J. (2004). Language, Society and Power: An Introduction (2nd ed.). London, New York: Routledge. 


\section{Macrothink}

International Journal of Linguistics

ISSN 1948-5425

2020, Vol. 12, No. 4

Van Dijk, T. (1996). Discourse, Power and Access. In C. R. Caldas-Coulthard, \& M. Coulthard (Eds.), Texts and Practices. Readings in Critical Discourse Analysis (pp. 84-104). London: Routledge.

Van Dijk, T. (1997). What is Political Discourse Analysis?. In J. Blommaert, \& C. Bulcaen (Eds.) Political Linguistics (pp. 11-52). Amsterdam: Benjamins. https://doi.org/10.1075/bjl.11

Van Dijk, T. (2006). Discourse and Manipulation. Discourse \& Society, 17(2), 359-383. https://doi.org/10.1177/0957926506060250

Van Dijk, T. (2008). Discourse and power, Contributions to critical discourse studies. Houndsmills: Palgrave MacMillan.

Wardhaugh, R. (2006). An Introduction to Sociolinguistics. New York: Wiley-Blackwell.

Wartenberg, T. E. (1990). The Forms of Power: From Domination to Transformation. Philadelphia: Temple University Press.

Wodak, R. (2007). Pragmatic and Critical Discourse Analysis: A cross-disciplinary inquiry. Pragmatics and Cognition, 15(1), 203-225. https://doi.org/10.1075/pc.15.1.13wod

Wodak, R., \& Chilton, P. (2005). A new agenda in (critical) discourse analysis: Theory, methodology and interdisciplinarity. Discourse Approaches to Politics, Society, and Culture, 13. Amsterdam: John Benjamins.

Wodak, R., \& Meyer, M. (2001). Methods of Critical Discourse Analysis. London: Sage.

Wrong, D. H. (1997). Power: Its Forms, Bases, and Uses. New Brunswick: Transaction Publishers.

Ye, R. (2010). The Interpersonal Metafunction Analysis of Barack Obama's Victory Speech. English Language Teaching, 3(2), 146-151. https://doi.org/10.5539/elt.v3n2p146

Zaaiman, J. (2007). Power: towards a third generation definition. Koers, 72(3), 357-375. https://doi.org/10.4102/koers.v72i3.207

\section{Notes}

Note 1. Barack Obama's Victory Speech was delivered in Chicago, Illinois on November 4, 2008. A full transcript of the speech is available in the Appendix.

Note 2. Text available from http://www.armeniapedia.org/wiki/Radio_Yerevan_Jokes, retrieved on April 3, 2020.

Note 3. Full text available from https://www.ushistory.org/declaration/document/ (accessed on April 10, 2020).

Note 4. Full text available from https://www.ushistory.org/documents/gettysburg.htm (accessed on April 10, 2020). 
Note

5 .

Full

text

available

from

https://kinginstitute.stanford.edu/king-papers/documents/nonviolence-and-racial-justice (accessed on April 10, 2020).

Note 6. Full text available from https://www.ushistory.org/documents/gettysburg.htm (accessed on April 10, 2020).

Note 7. English text available from http://holocaust.umd.umich.edu/news/uploads/WanseeProtocols.pdf (accessed on April 10, 2020).

$\begin{array}{lllll}\text { Note } & 8 & \text { Full } & \text { text } & \text { available }\end{array}$ https://georgewbush-whitehouse.archives.gov/news/releases/2004/10/20041026-14.html (accessed on April 10, 2020).

Note 9. Full text is available from https://winstonchurchill.org/resources/speeches/1940-the-finest-hour/be-ye-men-of-valour/ (accessed on April 10, 2020).

Note 10. Great Seal of the USA, first appeared in 1782. Available from: http://www.greatseal.com/mottoes/unum.html, (retrieved April 4, 2020).

Note 11. The video clip of the Victory Speech is available at the official Obama YouTube channel and can be accessed from http://www.youtube.com/watch? $\mathrm{v}=\mathrm{Jll}$ bbaCAaQU\&hl=it (retrieved on April 4, 2020). For ease of reference, the frame time is displayed below each screenshot.

Note 12. "E pluribus unum" was probably conceived in origin by Virgil in his poem Moretum (1st century BC).

\section{Appendix}

Appendix 1. Full transcript of Barack Obama's Victory Speech

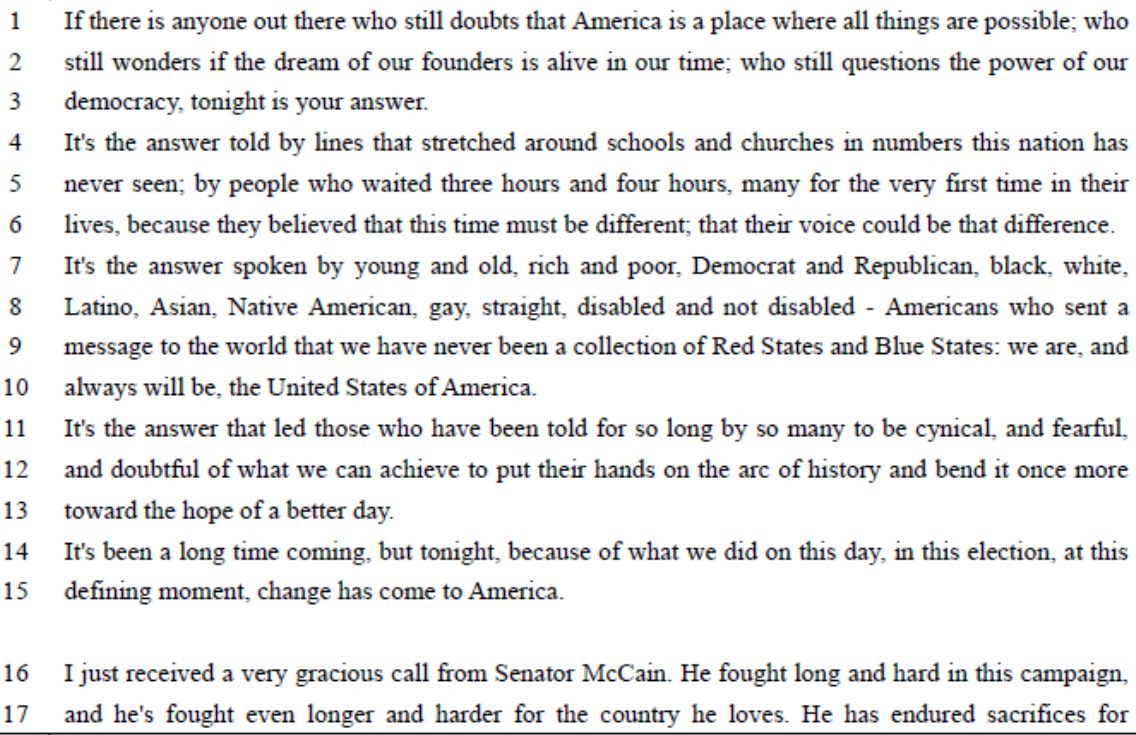


18 America that most of us cannot begin to imagine, and we are better off for the service rendered by

19 this brave and selfless leader. I congratulate him and Govemor Palin for all they have achieved, and I

20 look forward to working with them to renew this nation's promise in the months ahead.

21 I want to thank my partner in this journey, a man who campaigned from his heart and spoke for the

22 men and women he grew up with on the streets of Scranton and rode with on that train home to

23 Delaware, the Vice President-elect of the United States, Joe Biden.

24 I would not be standing here tonight without the unyielding support of my best fiiend for the last

25 sixteen years, the rock of our family and the love of my life, our nation's next First Lady, Michelle

26 Obama. Sasha and Malia, I love you both so much, and you have eamed the new puppy that's coming

27 with us to the White House. And while she's no longer with us, I know my grandmother is watching,

28 along with the family that made me who I am. I miss them tonight, and know that my debt to them is

29 beyond measure.

30 To my campaign manager David Plouffe, my chief strategist David Axelrod, and the best campaign

31 team ever assembled in the history of politics - you made this happen, and I am forever grateful for

32 what you've sacrificed to get it done.

33 But above all, I will never forget who this victory truly belongs to - it belongs to you.

34 I was never the likeliest candidate for this office. We didn't stat with much money or many

35 endorsements. Our campaign was not hatched in the halls of Washington - it began in the backyards

36 of Des Moines and the living rooms of Concord and the front porches of Charleston.

37 It was built by working men and women who dug into what little savings they had to give five

38 dollars and ten dollars and twenty dollars to this cause. It grew strength from the young people who

39 rejected the myth of their generation's apathy; who left their homes and their families for jobs that

40 offered little pay and less sleep; from the not-so-young people who braved the bitter cold and

41 scorching heat to knock on the doors of perfect strangers; from the millions of Americans who

42 volunteered, and organized, and proved that more than two centuries later, a government of the

43 people, by the people and for the people has not perished from this Earth. This is your victory.

44 I know you didn't do this just to win an election and I know you didn't do it for me. You did it

45 because you understand the enomity of the task that lies ahead. For even as we celebrate tonight, we

46 know the challenges that tomonow will bring are the greatest of our lifetime - two wars, a planet in

47 peril, the worst financial crisis in a century. Even as we stand here tonight, we know there are brave

48 Americans waking up in the deserts of Iraq and the mountains of Afghanistan to risk their lives for

49 us. There are mothers and fathers who will lie awake after their children fall asleep and wonder how

50 theyll make the mortgage, or pay their doctor's bills, or save enough for college. There is new energy

51 to hamess and new jobs to be created; new schools to build and threats to meet and alliances to

52 repair.

53 The road ahead will be long. Our climb will be steep. We may not get there in one year or even one

54 term, but America - I have never been more hopeful than I am tonight that we will get there. I

55 promise you - we as a people will get there.

56 There will be setbacks and false starts. There are many who won't agree with every decision or policy

57 I make as President, and we know that govemment can't solve every problem. But I will always be

58 honest with you about the challenges we face. I will listen to you, especially when we disagree. And

59 above all, I will ask you join in the work of remaking this nation the only way it's been done in 
60 America for two-hundred and twenty-one years - block by block, brick by brick, calloused hand by

61 calloused hand.

62 What began twenty-one months ago in the depths of winter must not end on this autumn night. This

63 victory alone is not the change we seek - it is only the chance for us to make that change. And that

64 cannot happen if we go back to the way things were. It cannot happen without you, without a new

65 spirit of service, a new spirit of sacrifice.

66 So let us summon a new spirit of patriotism; of service and responsibility where each of us resolves

67 to pitch in and work harder and look after not only ourselves, but each other. Let us remember that if

68 this financial crisis taught us anything, it's that we cannot have a thriving Wall Street while Main

69 Street suffers - in this country, we rise or fall as one nation; as one people.

70 Let us resist the temptation to fall back on the same partisanship and pettiness and immaturity that

71 has poisoned our politics for so long. Let us remember that it was a man from this state who first

72 carried the banner of the Republican Party to the White House - a party founded on the values of

73 self-reliance, individual liberty, and national unity. Those are values we all share, and while the

74 Democratic Party has won a great victory tonight, we do so with a measure of humility and

75 determination to heal the divides that have held back our progress. As Lincoln said to a nation far

76 more divided than ours, "We are not enemies, but fiiends... though passion may have strained it must

77 not break our bonds of affection." And to those Americans whose support I have yet to earn - I may

78 not have won your vote, but I hear your voices, I need your help, and I will be your President too.

79 And to all those watching tonight from beyond our shores, from parliaments and palaces to those

S0 who are huddled around radios in the forgotten comers of our world - our stories are singular, but our

81 destiny is shared, and a new dawn of American leadership is at hand. To those who would tear this

82 world down - we will defeat you. To those who seek peace and security - we support you. And to all

83 those who have wondered if America's beacon still bums as bright - tonight we proved once more

84 that the true strength of our nation comes not from our the might of our anms or the scale of our

85 wealth, but from the enduring power of our ideals: democracy, liberty, opportunity, and unyielding

86 hope.

87 For that is the true genius of America - that America can change. Our union can be perfected. And

88 what we have already achieved gives us hope for what we can and must achieve tomorrow.

89 This election had many firsts and many stories that will be told for generations. But one that's on my 90 mind tonight is about a woman who cast her ballot in Atlanta. She's a lot like the millions of others 91 who stood in line to make their voice heard in this election except for one thing - Ann Nixon Cooper 92 is 106 years old.

93 She was born just a generation past slavery; a time when there were no cars on the road or planes in

94 the sky; when someone like her couldn't vote for two reasons - because she was a woman and

95 because of the color of her skin.

96 And tonight, I think about all that she's seen throughout her century in America - the heartache and

97 the hope; the struggle and the progress; the times we were told that we can't, and the people who

98 pressed on with that American creed: Yes we can.

99 At a time when women's voices were silenced and their hopes dismissed, she lived to see them stand

100 up and speak out and reach for the ballot. Yes we can.

101 When there was despair in the dust bowl and depression across the land, she saw a nation conquer 
102 fear itself with a New Deal, new jobs and a new sense of common purpose. Yes we can.

103 When the bombs fell on our harbor and tyranny threatened the world, she was there to witness a

104 generation rise to greatness and a democracy was saved. Yes we can.

105 She was there for the buses in Montgomery, the hoses in Birmingham, a bridge in Selma, and a

106 preacher from Atlanta who told a people that "We Shall Overcome." Yes we can.

107 A man touched down on the moon, a wall came down in Berlin, a world was connected by our own

108 science and imagination. And this year, in this election, she touched her finger to a screen, and cast

109 her vote, because after 106 years in America, through the best of times and the darkest of hours, she

110 knows how America can change. Yes we can.

\section{Copyrights}

Copyright for this article is retained by the author(s), with first publication rights granted to the journal.

This is an open-access article distributed under the terms and conditions of the Creative Commons Attribution license (http://creativecommons.org/licenses/by/4.0/) 